imported hard wheat, which was formerly used to improve the baking qualities of bread made from Swedish native soft wheat. Investigations are also being carried out on synthetic rubber. The work has proceeded so far that the product has been evolved in the laboratories of the Institute, although it is too early yet to say whether domestic production can be started and its probable extent.

One of the foremost technical means of research of this Institute is the Svedberg ultra-centrifuge, which has become of the utmost importance to science. The rotor of this centrifuge is given a speed of up to 70,000 revolutions per minute by a number of oil turbines. The Institute also houses such instruments for research as one of the world's largest electro-magnets and a neutron generator, both of which have been made in Sweden. In the biochemical section the experiments for locating and cultivating infantile paralysis virus and tuberculine on the basis of a new method for analysing mixtures through molecule splitting are carried on under the direction of Prof. Arne Tiselius; who has devised this method. The object in the first place is to obtain a pure form of virus. The stoppage of the import of apes for these experiments for a while threatened the workers with the loss of indispensable test animals, but it is stated that their replacement with rats has now proved acceptable.

\section{Quality Control in Manufacture}

AN article by H. Rissik on "Quality Control in Manufacture" in the Electrician of March 27 reviews the principles of the subject with special reference to the use of control charts. The theoretical foundations of the method were laid down originally by Prof. R. A. Fisher, and the technique itself, which was originated in the Bell Telephone Laboratories of the United States, has been applied successfully for more than twelve years throughout the various manufacturing organizations of the Bell system. The technique of quality control is, briefly, one of inspection-cum-production, based on known statistical methods which have been applied successfully in other fields, and it has proved to be a valuable aid to manufacturing concerns engaged on repetition work. Its advantages include reduction in inspection costs and in rejects, attainment of maximum benefits from quantity production and of uniform product quality even though the inspection test be destructive, immediate applicability as part of inspection routine, and utter simplicity of application.

Fundamentally, the problem is one of controlling variability in some directly measurable quality characteristic, for example, dimension, weight, tensile strength, electrical resistance, hardness, etc. In practice this means analysing the variability observed and comparing it with some objective standard. Thus, provided a product is known beforehand to be stable, limits may be assigned within which practically all observed values of the variable quality characteristic are expected to lie. If measurements on a succession of piece-parts, produced supposedly under the same essential conditions, are found to give dimensional values lying outside these limits, then it may be inferred that they were not, in fact, so produced, that is, the production process was not stable in the first place. This leads to the very heart of quality control as a technique enabling preventive action to be taken before trouble develops; and the basis of this is the so-called quality control chart which is, in effect, a continuous graphical record of product quality. The article discusses the use of the control chart and makes reference to the recent British Standards Institution publications, B.S. 6001942 and B.S. 1008-1942.

\section{Electrical Instruments}

IN his chairman's address to the Meter and Instrument Section of the Institution of Electrical Engineers ( $J$. Inst. Elec. Eng., 89, Pt. I, No. 13, January, 1942), W. Phillips surveys the design and performance of electrical instruments. Development since the 1890's has been twofold: first in widening the limits of measurement, and secondly in accuracy. Switchboard moving-coil instruments are now available to give full-scale deflection for $10 \mu$ amp. or less, and ammeters having a range of 30,000 amp. are in use. In voltage, the range is from a few micro-volts, with apparently no upper limit, the sensitivity of D.c. moving-coil instruments now being limited only by the non-magnetic quality of the moving system. The standardization of frequency at $50 \mathrm{c.} / \mathrm{s}$. , and its close regulation by supply undertakings, has fostered the design and use of testing apparatus for the measurement of power factor, peak factor, and current; and also of voltage testing sets and similar apparatus for use at fixed frequency. The Electricity Supply (Meters) Act created an immediate demand for standard and sub-standard instruments of all types, large sums being expended by supply authorities in equipping meter-testing stations. Great improvements in wattmeter performance have been made, particularly in the reduction of self-heating error and D.c./A.c. change-over error.

One of the recent major troubles with which instrument makers have had to cope is the almost complete stoppage of supplies of sapphire jewels. An English company now manufactures sapphire jewels from rough boules, but it cannot yet meet the demand. Substitutes are being provided, con. sisting of nitralloy steel jewels for meters, while for instruments a specially hard glass jewel is available requiring no expensive or elaborate manufacturing plant. The jewels at present being manufactured are mainly for use in miniature instruments, a small number only having been made for larger instruments.

\section{Electric Heating of Premises}

Mr. W. GrLChRIST, in a paper read recently before the Institution of Electrical Engineers on the above subject, deals with the various methods of applying electricity to space-heating, water-heating and sundry special applications with particular reference to large-scale space- and water-heating installations. The author records the fundamental principles of design and some of the results obtained from certain methods of heat application which do not, in some respects, follow existing practice. The possible economic limits of using electricity for direct heating are related to the capacity of both commercial and domestic buildings, there being a definite limit to the size of such installations both from the consumer's and supplier's points of view. Details are given of certain combinations of radiant and convection heating to achieve maximum comfort con. ditions at a lower cost to consumer and supplier than other existing. methods. Examples are given of installations using a combination of thermal storage, local thermal storage and direct heating, and a method of applying water-heating to large installations is described which considerably improves the 
overall efficiency. A domestic electrification policy is outlined with special reference to space- and waterheating for working-class houses, and it is suggested that future policy in the domestic electrification of houses should be based on the use of a proportion of solid fuel for heating and water-heating.

\section{Bee-keeping in War-time}

AT a lunch of the Backs to the Land Club held on March 25, Dr. C. G. Butler, of the Rothamsted Experimental Station, gave an address on the place of bee-keeping in the national economy. As Dr. Butler pointed out, it appears to be the common idea that the value of the honey-bee lies in the honey it produces. From the point of view of national economy, however, its function as the pollinator for fruit and seed crops is of prime importance. Honey has not been found to contain any measurable quantity of vitamins, but its invert sugars make it very readily assimilated by the human body. It is therefore of special value in treating cases of shock; also invalids and young children. Dr. Butler stressed the undesirability of too many beginners taking up bee-keeping at the present time. The shortage of supplies, in his opinion, is such that established bee-keepers should have first claim on such supplies, rather than the novice knowing nothing at all about bees. There is evidence that in many places where large orchards, or areas of insect-pollinated seed crops are planted, there are insufficient wild pollinating insects present for full production. Dr. Butler urges that, at the present time, greater efforts should be made to use honey-bees for pollination by making them available by the transfer of stocks to such areas where they are most needed.

\section{Wilhelm August Lampadius (1772-1842)}

Ax the time when geologists and mining students flocked to the Freiberg Mining Academy in Saxony, and when Gottlob Werner was at the height of his fame, a twenty-year-old chemist because a member of the staff, and from that time onwards for half a century he taught, wrote and experimented with great success. This young chemist was Wilhelm August Lampadius, who in his fourteenth year had been apprenticed to a Göttingen apothecary. Born at Hehlen in Brunswick on August 8, 1772, Lampadius lost his father, a pastor, at an early age. Apprenticed by his mother at Göttingen he devoted his spare time to study and was befriended by the university professors J. F. Gmelin and Lichtenburg. At the age of nineteen he entered the service of the metallurgist Count Sternberg of Bohemia. With the Count he made a journey to Russia and in the Count's laboratory made experiments on electricity and heat. His talents becoming known to Werner, he was given a post at Freiberg and on the death of C. E. Gellert (1713-1795) he was made professor of chemistry. In this situation he assisted German industry in many ways. He spread a knowledge of Lavoisier's discoveries, and made researches connected with mining and metallurgy, chemical manufactures, agriculture and meteorology. Especially important among the books he published was his handbook on smelting. A man of estimable character, respected alike by his friends and colleagues, he died at Freiberg on April 13, 1842) in his seventieth year. Fis place in the Academy was taken by Karl Friedrich Plattner (1800-1858), the chief of the royal department of assaying and an authority on the use of the blow pipe.

\section{Earthquakes Registered at Kew}

DURING February 2-March 5 four large earthquakes were registered on the seismographs at Kew Observatory. The first, on February 2; began recording at $17 \mathrm{~h} .15 \mathrm{~m}$. 28s. U.T., possibly from an epicentral distance of $1,500 \mathrm{~km}$., though long waves were not pronounced and the shock appeared to possess some of the deep-focus characteristics. On February 16 a strong shock began recording at $18 \mathrm{~h}$. $27 \mathrm{~m}$. 3ls. U.T., possibly from an epicentral distance of $13,300 \mathrm{~km}$. It finished recording at $20 \mathrm{~h} .00 \mathrm{~m}$., having lasted some $1 \mathrm{~h} .32 \cdot 5 \mathrm{~m}$. The third earthquake, on February 21, began recording on all three components with $i P$ compressional at $07 \mathrm{~h} .20 \mathrm{~m}$. 14s. The tentative calculated epicentral distance was $9,300 \mathrm{~km}$. The shock appeared to be normal, had a maximum ground amplitude at $\mathrm{Kew}$ of $72 \mu$, and finished recording at $09 \mathrm{~h} .40 \mathrm{~m}$. U.T. The third disturbance, on March 5, began recording near $19 \mathrm{~h}$. $59 \mathrm{~m}$. 56s. U.T., though the start of $i P$ was somewhat confused by microseisms. The epicentral distance may have been near $8,200 \mathrm{~km}$., the long waves were of small amplitude, and the shock finished recording at $21 \mathrm{~h} .10 \mathrm{~m}$. U.T.

\section{Announcements}

ON the joint recommendation of the presidents of the Royal Society and the Institution of Civil Engineers, the James Alfred Ewing Medal for 1941 has been awarded to Dr. F. W. Lanchester. The Medal is awarded annually for specially meritorious contributions to the science of engineering in the field of research.

THE first Sir Joseph J. Thomson Memorial Lecture of the Chemical Society will be given by Lord Rayleigh, in the Lecture Theatre of the Royal Institution on April 16 at 4.30 p.m.

Prof. B. K. MaLINowskr, University professor of anthropology in the London School of Economics who now holds the position of Bishop Museum visiting professor of anthropology in Yale University, has been appointed professor of cultural anthropology at that University as from July 1.

Prof. Emir Abderhalden, professor of physiology at Halle and for many years president of the German Academy of Natural Sciences at Halle, has had the latter appointment extended for another ten years.

Aт a meeting of the Quekett Microscopical Club, held on March 21, the following officers were elected : President, Mr. W. E. Watson Baker ; Hon. Librarian, Mr. C. Best ; Hon. Curator, Mr. C. Sidwell ; Hon. Secretary, Miss C. Arnold.

The following awards in respect of the year 1941 were made at the annual corporate meeting of the Institution of Chemical Engineers on March 27. The Osborne Reynolds Medal, for meritorious work accomplished for the advancement of the Institution during the year, to Dr. A. Parker, honorary editor and recorder of the Institution ; the Moulton Medal (in gold), for the best chemical engineering paper of the year, of a mature character, read before the Institution and published in the Transactions, to $\mathrm{Mr}$. P. Parrish, for his paper "Modern Developments in the Design of Plant for the Concentration of Sulphuric Acid"; the Junior Moulton Medal for 1941 was not awarded; the William Macnab Medal, for the best set of answers submitted in the associate-membership examination during the year, to Mr. E. W. Pates. 